\title{
Stroke and Amyloid- $\beta$ Downregulate TREM-2 and Uch-L1 Expression that Synergistically Promote the Inflammatory Response
}

\author{
Michela Guglielmotto ${ }^{\mathrm{a}, \mathrm{b}}$, Ivan Enrico Repetto ${ }^{\mathrm{c}}$, Debora Monteleone ${ }^{\mathrm{a}, \mathrm{b}}$, Valeria Vasciaveo ${ }^{\mathrm{a}, \mathrm{b}}$, \\ Claudio Franchino $^{\mathrm{d}}$, Sara Rinaldi ${ }^{\mathrm{a}, \mathrm{b}}$, Massimo Tabaton ${ }^{\mathrm{e}, *}$ and Elena Tamagno ${ }^{\mathrm{a}, \mathrm{b}, *}$ \\ ${ }^{a}$ Department of Neuroscience, University of Torino, Torino, Italy \\ ${ }^{\mathrm{b}}$ Neuroscience Institute Cavalieri Ottolenghi Foundation (NICO), University of Torino, Torino, Italy \\ ${ }^{\mathrm{c}}$ École Polytechnique Fédérale de Lausanne, Switzerland \\ ${ }^{\mathrm{d}}$ Department of Drug Science and Technology, University of Torino, Torino, Italy \\ ${ }^{\mathrm{e}}$ Department of Internal Medicine and Medical Specialties (DIMI), Unit of Geriatric Medicine, \\ University of Genova, Genova, Italy
}

Location of work: University of Torino Neuroscience Institute of Cavalieri Ottolenghi Foundation (NICO), University of Torino, Torino, Italy.

Accepted 22 July 2019

\begin{abstract}
Neuroinflammation is involved in the pathogenesis of Alzheimer's disease, and the transcription factor NF- $\kappa \mathrm{B}$ is a player in this event. We found here that the ischemic damage alone or in association with $A \beta_{1-42}$ activates the NF- $\kappa \mathrm{B}$ pathway, induces an increase of BACE1 and a parallel inhibition of Uch-L1 and TREM2, both in vitro and in vivo, in Tg 5XFAD and in human brains of sporadic AD. This mechanism creates a synergistic loop that fosters inflammation. We also demonstrated a significant protection exerted by the restoration of Uch-L1 activity. The rescue of the enzyme is able to abolish the decrease of TREM2 and the parameters of neuroinflammation.
\end{abstract}

Keywords: Alzheimer's disease, neuroinflammation, NF-kB pathway, stroke, TREM2, Uch-L1

\section{INTRODUCTION}

Advances in molecular pathogenesis suggest that chronic inflammation is a shared mechanism in the initiation and progression of multiple neurodegenerative diseases, such as Alzheimer's disease (AD) [1].

\footnotetext{
*Correspondence to: Elena Tamagno, Neuroscience Institute Cavalieri Ottolenghi, University of Torino; Regione Gonzole 10, 10043, Orbassano, Torino, Italy. Tel.: +39 0116706604; E-mail: elena.tamagno@unito.it and Massimo Tabaton, Department of Internal Medicine and Medical Specialties (DIMI), Viale Benedetto XV, 6, 16132, Genova, Italy. Tel./Fax: +390103537064; E-mail: mtabaton@neurologia.unige.it.
}

A consequence of the increased inflammatory signaling is the upregulation of the transcription factor $\mathrm{NF}-\kappa \mathrm{B}$ with subsequent neuroprotective or deleterious effects depending on the strength of the signal and the type of NF- $\kappa \mathrm{B}$ family dimers activated. Therefore, this pathway has been proposed to foster the progression of neurodegenerative diseases through its role in inflammation and apoptosis, but also beneficial effects in neuronal survival, differentiation, neurite outgrowth, and synaptic plasticity (for review, see [2]). NF- $\kappa$ B regulates the transcription of target genes in neurons implicated in AD progression [3]. $\mathrm{NF}-\kappa \mathrm{B}$ increases the expression of BACE1, and the 
disruption of $\mathrm{p} 65$, a crucial trans-activating subunit of the pathway, decreases BACE1 expression $[4,5]$. We previously found that amyloid- $\beta(A \beta)_{1-42}$ was able to significantly increase BACE1 expression and activity through NF- $\kappa \mathrm{B}$ activation both in vitro and in vivo, and that the increase in BACE1 expression is concomitant with the decrease in the expression of Ubiquitin C Terminal Hydrolase (Uch)-L1 [6, 7]. The decrease of Uch-L1 depends on the NF- $\kappa$ B pathway since p65 interacts with a binding sequence of the Uch-L1 gene promoter [8]. Uch-L1 is an abundant neuronal protein [9] that appears to have two enzymatic activities. The first one, known as hydrolase, removes and recycles ubiquitin molecules from the degraded proteins. The second one, called ubiquitin ligase, links ubiquitin molecules, thus generating polyubiquitin chains that tag protein for disposal [10].

The pathogenesis of many neurodegenerative diseases, including $\mathrm{AD}$, is associated with the downregulation of the proteasome system [11]. Indeed, Uch-L1, the limiting step of proteasomal degradation, is decreased in AD brains [12,13], and its level is inversely proportional to the amount of tau pathology [14]. It has been proposed that Uch-L1 also plays a role in preventing neuroinflammation, as Ichikawa et al. [15] demonstrated that the upregulation of Uch-L1 causes a negative feedback to the neuroinflammation induced by TNF- $\alpha$.

Recently, it has been demonstrated that lipopolysaccharide (LPS) negatively regulates the expression of triggering receptor expressed on myeloid cell (TREM) 2 protein through the activation of NF$\kappa \mathrm{B}$ signaling pathway [16]. TREMs are family cell surface receptors expressed on myeloid cells. Particularly, TREM1 is a powerful amplifier of the inflammatory response, whereas TREM2 displays an anti-inflammatory action $[17,18]$. Of note, loss of function mutations of TREM2 are associated to a disorder known as Nasu-Hakola disease [19], a rare autosomal recessive disorder characterized by presenile dementia, but also to the increased risk to develop $\mathrm{AD}[20]$.

We show here that stroke, as well as $A \beta_{1-42}$, drastically decrease the expression of both TREM 2 and Uch-L1 in hypoxic primary cortical neurons, as well as in animal model of $A \beta_{1-42}$ accumulation exposed to cerebral stroke, through the activation of NF- $\kappa$ B pathway. These events resulted in a vicious cycle that promotes the inflammatory response. Moreover, the restoration of Uch-L1 activity significantly protects the inflammatory injury.

\section{MATERIAL AND METHODS}

Animals

2-month-old no carrier (control mice) and B6SJL-Tg (APPSwFILon,PSEN1* M146L*L286V) 6799Vas/Mmjax (5XFAD Tg mice) were used for producing the ischemic injury. Experimental procedures involving the use of live animals have been carried out in accordance with the guidelines established by the European Community Directive 86/609/EEC (November 24, 1986), Italian Ministry of Health, and the University of Turin (law 116/92 on Care and Protection of living animals undergoing experimental or other scientific procedures; authorization number 17/2010-B, June 30, 2010). Moreover, the Ethical Committee of the University of Turin approved this type of studies. The animals were maintained under $12 \mathrm{~h}$ light/dark cycles and were provided with water and food ad libitum (standard mouse chow 4RF25-GLP, Mucedola srl, Settimo Milanese, Italy). Specifically, all the procedures were carried out in order to minimize the pain and distress in the animals and we used the fewest number of animals required to obtain statistically significant data.

\section{Permanent focal ischemia}

Adult male mice underwent a proximal middle cerebral artery (MCA) electrocoagulation as previously described [21]. Briefly, we used $4 \%$ isoflurane (Isoflurane-Vet 100\%, Liquid, Merial Italy, Milan, Italy) vaporized in $\mathrm{O}_{2} / \mathrm{N}_{2} \mathrm{O}$ 50:50 to deeply anesthetize control and transgenic mice. During surgery, anesthesia was maintained at $1.5 \%-2.5 \%$ isoflurane while mice were placed on their left side on top of a feedback-controlled heating blanket to maintain the temperature at $37^{\circ} \mathrm{C}$ with the use of a rectal thermometer. The temporalis muscle was retracted and the temporalis skull exposed to make a $2 \mathrm{~mm}$ diameter hole with a micro dental drill to locate the MCA underneath. After removing the meninges, the MCA was carefully cauterized with the usage of a bipolar forceps (Jeweler 30665, GIMA, Milan, Italy).

Once the MCA has been cauterized, the surgery wound closed with suture. The mice were finally moved to a warmed cage.

After $24 \mathrm{~h}$, the mice were sacrificed with an overdose of anesthetic and the brain collected and processed for western blot analysis.

For another group of animals, after $24 \mathrm{~h}$, the mice were sacrificed with an overdose of anesthetic, 
perfused with $4 \%$ paraformaldehyde (PFA) in $0.1 \mathrm{M}$ phosphate buffer (PB, pH 7.4), and the brains collected and processed for Cresyl-violet staining to assess the lesion volume.

\section{Histological assessment of ischemic lesion}

Brains were removed from the skull and post fixed in the same fixative (PFA 4\%) for $4 \mathrm{~h}$. The tissue was cryoprotected by immersion in buffered $30 \%$ sucrose overnight, embedded, and frozen in cryostat medium (Bio-Optica, Milan, Italy). The brains were cut into coronal, $25 \mu \mathrm{m}$ thick, free-floating sections, and stored in a cryoprotective solution at $-20^{\circ} \mathrm{C}$ until being processed for Cresyl-violet (2\%) staining.

Infarct size and brain edema were calculated using Neurolucida Software (MBF Bioscience 11 ver.).

The volumes of edema were calculated by subtracting the contralateral hemisphere volume from the ischemic hemisphere volume; for edema correction, the equation ischemic volume contralateral hemisphere/ipsilateral hemisphere volume was used, as previously described [22].

\section{Mouse primary neuronal cell culture}

Embryonic cortical neurons were isolated by standard procedures. E16.5 embryonic cerebral cortices were transferred to a petri dish with Digestion buffer on ice (HBSS without $\mathrm{CaCl} 2$ and $\mathrm{MgCl} 2$ (Gibco. Cat $\left.\mathrm{n}^{\circ} 14175-053\right)+1 \%$ glucose $\left.1 \mathrm{M}+1 \% \mathrm{BSA}\right)$, treated with Papain Solution (Worthngton (PAPL) +Dnasi I $15 \mathrm{Ku}$, Sigma, D5025-0.2 mg/ml) and dissociated into single cells by gentle trituration. Cells suspension was filtered with a cell strainer $100 \mathrm{um}$, centrifuged at $900 \mathrm{RPI}$ for $3 \mathrm{~min}$. Cells were suspended in Neurobasal medium supplemented with $2 \%$ B27, $1 \%$ L-Glutamine, and 10\% FBS (fetal bovine serum, low $\operatorname{IgG})$, then plated on dishes coated with poly-LLysine $(0.1 \mathrm{mg} / \mathrm{ml}$ - Sigma P7405) and plated at 400 cells $/ \mathrm{mm}^{2}$. After $3-4 \mathrm{~h}$ of incubation at $37^{\circ} \mathrm{C}$ in a $\mathrm{CO}_{2}$ incubator, the medium was changed with Neurobasal medium supplemented with low FBS $(2.5 \%$ fetal bovine serum, dyalized). After 2 days, the medium was replaced with Neurobasal medium without FBS. We changed half of the volume of the medium weekly for an equal volume of a fresh solution.

Two weeks after, embryonic cortical neuronal cells were exposed to hypoxia up to $12 \mathrm{~h}$. Furthermore, some culture dishes were pretreated with a fresh preparation of $A \beta_{1-42}$ peptides (ANASPEC, 24224) at the final concentration of $1 \mu \mathrm{M}$. Finally, the cells were also treated with TAT fusion protein (V-Uch-L1) $100 \mathrm{nM}$ before hypoxia exposition, as single treatment or as co-treatment together with $A \beta_{1-42}$.

\section{Human brain tissues}

We used frozen cerebral cortex (superior frontal gyrus) from two groups of patients: 1) 26 control cases: the mean age of death was 73 years \pm 9 and the postmortem delay $9.2 \mathrm{~h}$, and 2) 32 cases with late onset sporadic AD with clinical history according to the Consortium to establish a Registry for Alzheimer's Disease (CERAD) criteria, provided by the brain bank of Case Western Reserve University, Cleveland, OH, USA. The mean of death was 78 years \pm 10 and the postmortem delay was $10.2 \mathrm{~h}$.

Expression and purification of recombinant TAT fusion proteins

TAT-fused Uch-L1 was provided by Dr. Ottavio Arancio (Columbia University); the construct was obtained as described by Gong et al. [23] and was fused with TAT peptide for brain delivery.

Briefly, TAT vectors were transformed into E. Coli BL21(DE3) pLysS competent cells (Novagen), and the obtained colonies were grown as $1 \mathrm{ml}$ overnight cultures in Luria broth (LB) medium (Sigma-Aldrich) with $100 \mathrm{mg}$ ampicillin, in the presence of $100 \mathrm{mM}$ IPTG. Then the cultures were transferred to $500 \mathrm{ml}$ LB ampicillin plus $200 \mathrm{mM}$ IPTG to obtain largescale preparations. Fusion proteins were purified according to ProBond purification system (Invitrogen).

VUch-L1 fusion proteins were i.p. injected into mice at $0.03 \mathrm{~g} / \mathrm{kg}, 20 \mathrm{~min}$ before the Rose Bengal injection and surgery procedure. After 6 or $12 \mathrm{~h}$, mice were sacrificed and protein extracts were prepared and examined as described below.

\section{Antibodies and immunoblot analyses}

The following antibodies were used for immunoblotting analyses: BACE1 (Millipore, AB5940, 1:500), BAX (Santa Cruz Biotechnology, Sc-493, 1:100); Bcl-2 (Santa Cruz Biotechnology, Sc-509, 1:200); Caspase 3 (Cell Signaling Technology, 9665, 1:1000), TREM 2 (Novusbio, NPB1-07101, 1:1000), and $\beta$ actin (Sigma-Aldrich, A5441, 1:5000). 


\section{Cell and tissue extracts}

Total extracts were obtained from a $20 \%(\mathrm{w} / \mathrm{v})$ mouse brain homogenate in RIPA buffer containing $0.5 \%$ Nonidet P-40, $0.5 \%$ sodiumdeoxycholate, $0.1 \% \mathrm{SDS}, 10 \mathrm{mmol} / \mathrm{l} \mathrm{EDTA}$, and protease inhibitors. After 40 min of incubation in ice, the homogenates were cleared by centrifugation at $15,000 \mathrm{~g}$ at $4{ }^{\circ} \mathrm{C}$ for $40 \mathrm{~min}$. Supernatants were removed and stored.

Preparation of cell lysates were obtained in icecold buffer consisting of $20 \mathrm{mM}$ Tris- $\mathrm{HCl}$ pH7.4, $150 \mathrm{mM} \mathrm{NaCl}, 2 \mathrm{mM}$ EGTA, $1 \mathrm{mM}$ EDTA, $1 \%$ Triton $^{\mathrm{TM}_{-} \mathrm{X}-100,1 \mathrm{mM} \text { PMSF, phosphatase and pro- }}$ tease inhibitors and then centrifuged at $12,000 \mathrm{rpm}$ for $20 \mathrm{~min}$ at $4^{\circ} \mathrm{C}$ to obtain soluble proteins. In both experiments the protein content was determined using the Bradford assay. Protein extracts were stored at $-80^{\circ} \mathrm{C}$ until use.

\section{Western blotting}

Lysates $(20 \mu \mathrm{g})$ were run on $4-12 \%$ Tris- $\mathrm{HCl}$ gradient PAGE gel (Invitrogen) and then transferred to nitrocellulose blotting membrane (Ge Healthcare 10600008). Peroxidase-conjugated secondary antibodies were incubated for $1 \mathrm{~h}$ at room temperature (RT) and revealed with Luminata Forte Western substrate (WBLUF0100, Millipore). The correct protein loading was controlled normalizing with $\beta$ actin antibody.

\section{MTT assay}

The cells vitality was assessed with a commercial kit (Sigma, St. Louis, MO, USA). Solutions of MTT, dissolved in medium or balanced salt solutions without phenol red, are yellowish in color. Mitochondrial dehydrogenases of viable cells cleaved the tetrazolium ring, yielding purple formazan crystals which are insoluble in aqueous solutions. The crystals are dissolved in acidified isopropanol. The resulting purple solution is spectrophotometrically measured.

\section{Hydrolase activity assay}

The hydrolase activity assay was performed using the fluorogenic ubiquitin-7-amino-4-methylcoumarin (ubiquitin-AMC) (Boston Biochem, Cambridge, MA, USA) substrate diluted in an assay buffer $(50 \mathrm{mM}$ Tris-HCl pH 7.6, $0.5 \mathrm{mM}$ EDTA, $5 \mathrm{mM}$ DTT, and $0.1 \mathrm{mg} \mathrm{mL}$ ovalbumin). The reaction mixture containing $400 \mathrm{nM}$ substrate and $100 \mu \mathrm{g}$ protein samples was incubated for $5 \mathrm{~min}$ at room tem- perature and the enzymatic activity was measured using a fluorescence spectrometer (LS55; Perkin Elmer Instruments, Waltham, MA, USA) at $25^{\circ} \mathrm{C}$ (EX $380 \mathrm{~nm}$ and EM460 nm) [6].

$N F-\kappa B$ activity

The activity of NF- $\kappa$ B was measured using a commercially available kit (Active Motif, Rixensart, Belgium). The NF- $\kappa \mathrm{B}$ contained in the nuclear extracts specifically binds to an oligonucleotide containing an NF- $\kappa \mathrm{B}$ consensus binding site. The primary antibodies recognize epitopes on p65, p50, p52, Rel B and RelC proteins upon DNA binding [6].

\section{TNF alpha production}

The production of TNF alpha was measured using a commercially available kit (MyBioSource.com, San Diego, CA, USA). The MyBioSource' Mouse TNF alpha Elisa is an in vitro enzyme-linked immunosorbent assay for the detection and quantification of endogenous levels of natural and/or recombinant Mouse TNF alpha proteins within the range of $7.8 \mathrm{pg} / \mathrm{ml}-500 \mathrm{pg} / \mathrm{ml}$.

\section{IL-6 production}

The cytokine production was measured using a commercially available kit (MyBioSource.com, San Diego, CA, USA). The MyBioSource' Mouse IL-6 Elisa is an in vitro enzyme-linked immunosorbent assay for the detection and quantification of endogenous levels of natural and/or recombinant Mouse IL-6 protein within the range of $31.2 \mathrm{pg} / \mathrm{ml}-2000 \mathrm{pg} / \mathrm{ml}$.

\section{Statistical analysis}

Statistical analyses were performed using GraphPad Prism version 4.0 (GraphPad software, San Diego). All values were presented as mean \pm standard error (SEM). Means were compared by one or two-way analysis of variance (ANOVA) with Bonferroni as a post-hoc test [24].

\section{RESULTS}

Hypoxia and $A \beta_{1-42}$ activate $N F-\kappa B$ pathway, and induce apoptotic and necrotic cell death in primary cortical neuronal cells

We studied this pathway because it had been previously demonstrated that the activation of NF- $\kappa$ B 
abolishes Uch-L1 gene transcription [25] and regulates the transcription of genes involved in $\mathrm{AD}$ progression [3].

We observed that the cells exposed to $1 \mathrm{~h}$ of hypoxia show a significant nuclear activation of the pathway; the simultaneous presence of hypoxia and $\mathrm{A} \beta_{1-42}$ mediates an additional effect on the activation of the signal pathway (Hypoxia $+50 \%$ versus control; Hypoxia $+A \beta_{1-42}+130 \%$ ) (Fig. 1A). After 12 and $24 \mathrm{~h}$ of hypoxia, we observed an increase of pro-apoptotic parameters $(\sim+100 \%$ cleaved caspase 3 and $\sim+160 \%$ Bax), while the levels of the Bcl-2 antiapoptotic protein are reduced $(\sim-50 \%)$ (Fig. 1B). The addition of $A \beta_{1-42}$ exacerbates the phenomenon leading to an increase in the pro-apoptotic parameters $(\sim+250$ for both parameters) and a decrease in Bcl-2 $(\sim-75 \%)$; these results are also significant if compared with cells incubated in hypoxia alone. The cell viability is reduced after $24 \mathrm{~h}$ of hypoxia (20\% viability) (Fig. $1 \mathrm{C}$ ), the addition of $\mathrm{A} \beta_{1-42}$ reduced neuronal viability as early as $12 \mathrm{~h}(40 \%$ viability).

\section{$N F-\kappa B$ activation is followed by Uch-L1 and TREM-2 downregulation as well as by overproduction of IL-6 and TNF $\alpha$}

As we expected, both experimental conditions (hypoxia and/or $A \beta_{1-42}$ ) are also able to inhibit the activity of Uch-L1 in primary mouse cortical cells.

Figure 2A shows the hydrolase activity measured in cells placed in hypoxia and treated or not with $A \beta_{1-42}$. We observed that the hypoxic condition causes a decrease of the hydrolase activity after 6 $\mathrm{h}(-60 \%)$; the addition of $\mathrm{A} \beta_{1-42}$ leads to an earlier decrease of the activity which is already after $3 \mathrm{~h}$ (Fig. 2B).

We and others have previously shown that the activation of NF- $\kappa \mathrm{B}$ is also related to an overexpression of BACE1 [4, 7]. We verified BACE1 protein levels increase (data not shown).

Hypoxia significantly decreases the protein levels of TREM $2(-40 \%$ after $6 \mathrm{~h})$, while the concomitant presence of $A \beta_{1-42}$ induces a more drastic and earlier decrease $(-60 \%$ at $3 \mathrm{~h})$. It is well known that the decrease of TREM 2 expression further augments the production of inflammatory cytokines, such as IL- 6 and TNF- $\alpha$, leading to detrimental exacerbation of neuroinflammation [26, 27]. As we expected, the decline in TREM 2 is followed by an increase in the release of the two cytokines (Fig. 2C, D).
Restoration of Uch-L1 activity rescues the decrease of TREM2 and the increase of BACE1 protein levels as well as the cytokine production

To restore the activity of Uch-L1 we pretreated cortical neuronal cells with a fusion protein between transduction domain of the HIV-transactivator protein (TAT), fused with a HA tag and Uch-L1, immediately before the ischemic injury and/or $\mathrm{A} \beta_{1-42}$ treatment.

Treatment with the TAT peptide restores the activity of the enzyme as demonstrated by the evaluation of the hydrolase activity (Fig. 3A). As shown in Fig. 3B and $\mathrm{C}$, the restoration of the Uch-L1 activity abolishes the TREM2 decrease (Fig. 3B) and BACE1 increase (Fig. 3C). The treatment with Uch-L1 TAT peptide restores the production of IL6 (Fig. 3D) and TNF $\alpha$ (Fig. 3) to control values; in co-presence of $A \beta_{1-42}$, the production of cytokines is reduced but the levels are still slightly higher compared with the control cells.

To investigate whether the decrease in Uch-L1 activity could be directly responsible for the decrease in TREM2, we treated cortical cells, up to $12 \mathrm{~h}$ in normoxic conditions, with $5 \mu \mathrm{M}$ LDN-57444 (LDN), a reversible Uch-L1 inhibitor. Figure 4A shows that the treatment with LDN is followed by a drastic decrease $(-40 / 60 \%)$ of total hydrolase activity. Figure $4 \mathrm{~B}$ shows the basal levels of TREM 2 and BACE1 in the presence of the Uch-L1 inhibition. As expected, the levels of BACE1 were significantly higher than the control cells $(+80 / 100 \%)$. The inhibition of Uch-L1 caused a significant decrease in TREM2 $(-50 / 80 \%)$.

\section{The link between Uch-L1, TREM2, and BACE1 and neuroinflammation is confirmed in Tg mouse}

We have performed experiments in control mice and in 5xFAD Tg mice subjected or not to ischemic injury and sacrificed after $12 \mathrm{~h}$. Figure $5 \mathrm{~A}$ shows that the infarct area is similar both in control and Tg mice, and that the pre-treatment with Uch-L1 TAT peptide does not change the size of the infarct area. Ischemia determined a strong increase in peri-infarctual edema in the $\mathrm{Tg}$ mice compared to the control animals. The restoration of the Uch-L1 activity reduced the amount of edema (-30-40\%) (Fig. 5B). Moreover, in both control and transgenic animals, the ischemic damage caused a decrease in TREM 2 and a parallel increase in BACE1; with the pre-treatment 


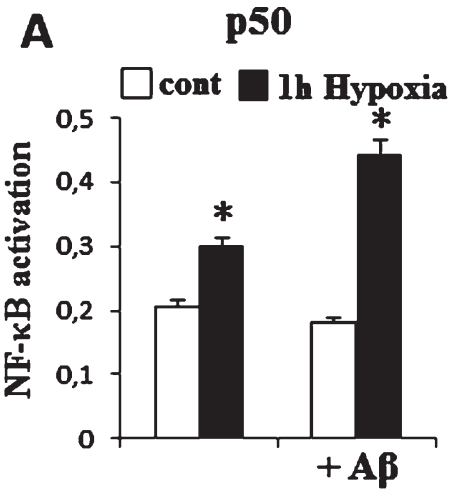

Rel C

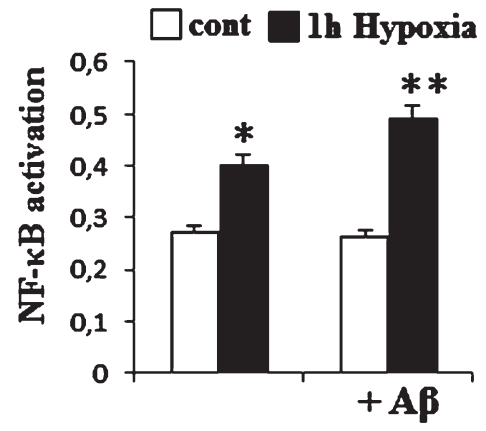

p65

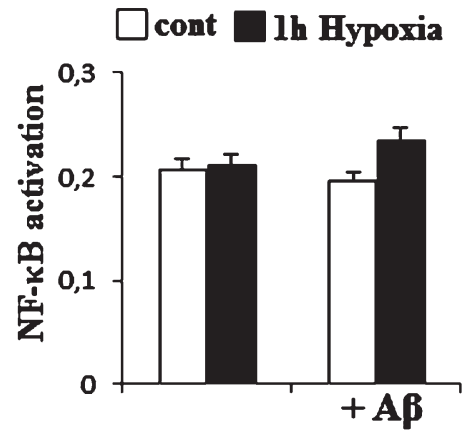

p52
Rel B

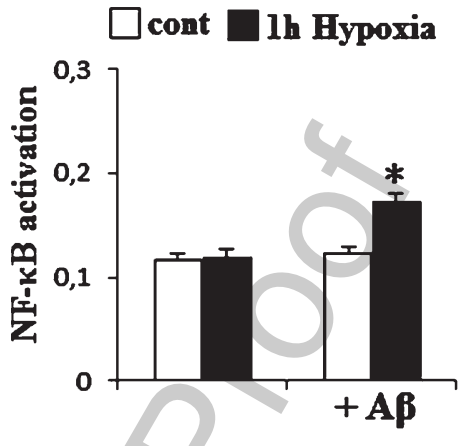

Total NF-kB

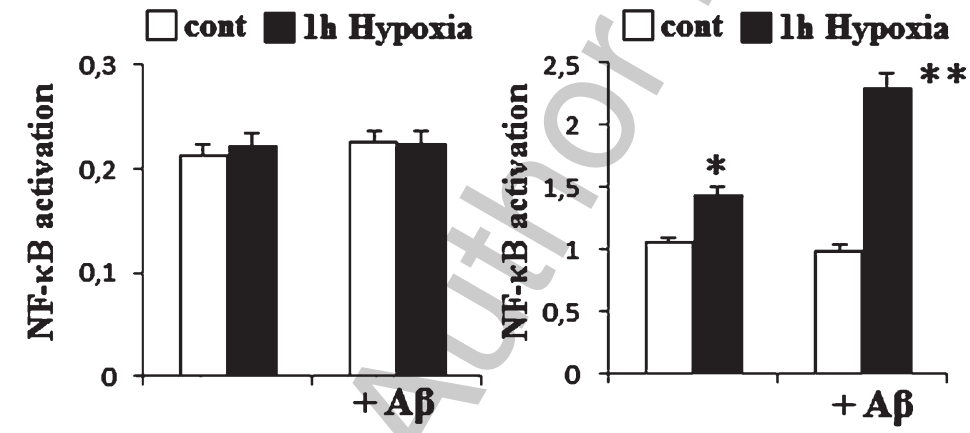

C
B

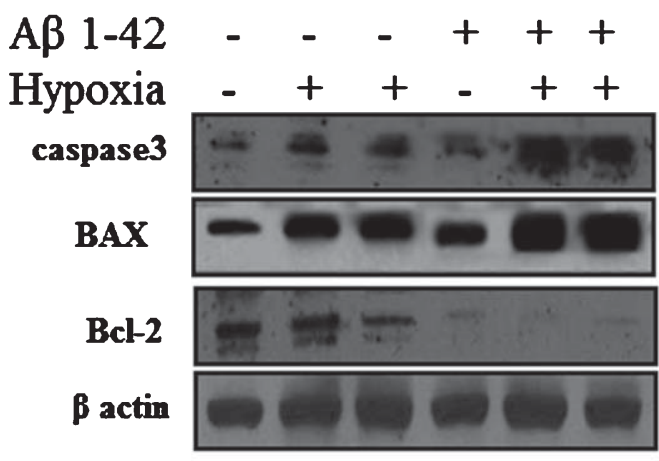

Densitometric analysis

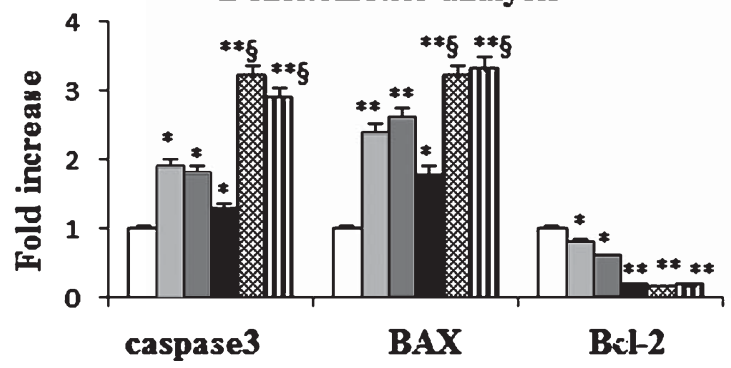

MTT

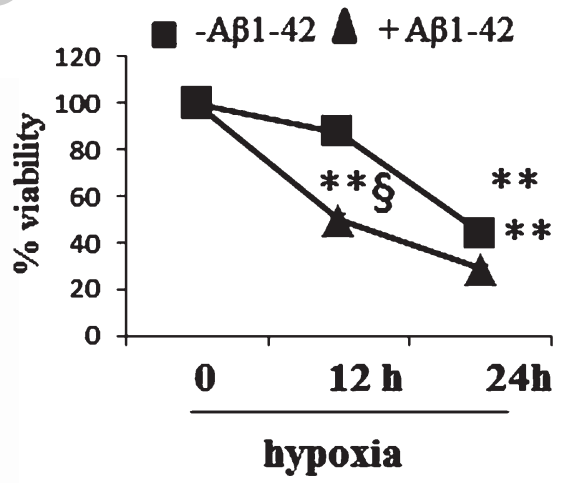

ctr

Hyp 12h

Hyp 24h

Ap1-42

Hyp 12h + Aß1-42

III Нyp 24H + Aß1-42 
B
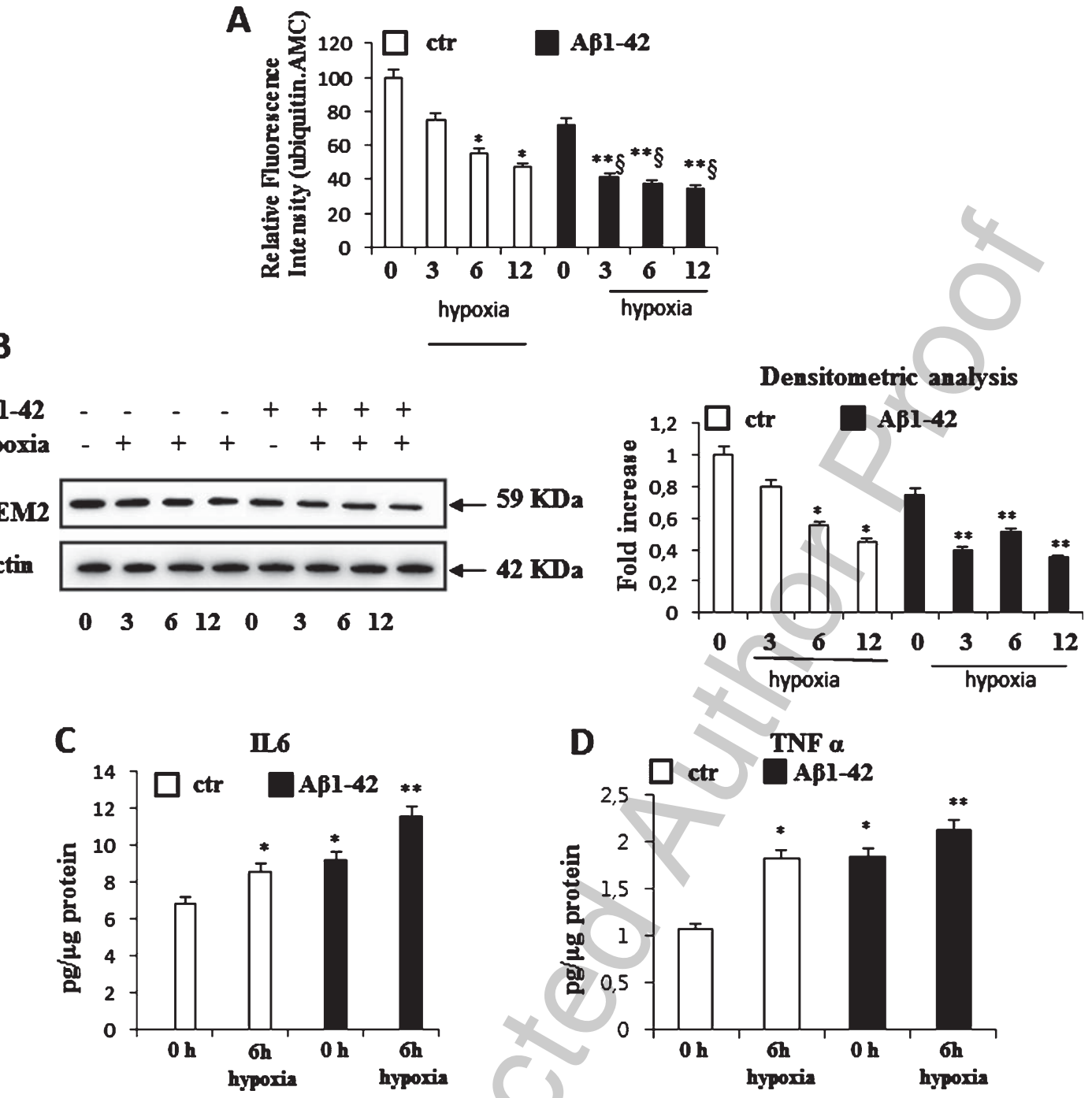

Fig. 2. NF- $\kappa$ B activation is followed by Uch-L1 and TREM2 downregulation and a parallel increase in inflammatory cytokines production. A) Hydrolase activity in cortical neurons exposed up to $12 \mathrm{~h}$ hypoxia with or without $\mathrm{A} \beta_{1-42}$. Hypoxic condition causes a significant decrease of the hydrolase activity after $6 \mathrm{~h}$, whereas the addition of $A \beta_{1-42}$ leads to an earlier decrease of the activity that results significant already after $3 \mathrm{~h}$. B) Representative western blot of cortical neurons lysates exposed up to $12 \mathrm{~h}$ hypoxia with or without A $\beta_{1-42}$ using TREM 2 antibody. $\beta$ actin served as loading control. Densitometric analysis shows that hypoxia significantly decreases the protein levels of TREM2 while the concomitant presence of $A \beta_{1-42}$ induces a higher and earlier decrease. C, D) Production of IL-6 and TNF $\alpha$ in cells exposed to $6 \mathrm{~h}$ hypoxia with or without $A \beta_{1-42}$. The decrease in TREM 2 was followed by a significant increase in the release of the two cytokines studied. Experiments are conducted in triplicate. The data are the mean \pm standard error $(\mathrm{SEM}) .{ }^{*} p<0.05$ versus control; ${ }^{* *} p<0.02$ versus control; $p<0.05$ versus hypoxia alone.

Fig. 1. Hypoxia and $A \beta_{1-42}$ activate the NF- $\kappa \mathrm{B}$ pathway, and induce apoptotic and necrotic cell death in primary cortical neuronal cells. A) Total NF- $\kappa$ B levels have been measured by screening all members of NF- $\kappa$ B family. One hour hypoxia significantly increases NF- $\kappa \mathrm{B}$ activation; the co-presence of $A \beta_{1-42}$ has an additive effect. B) Representative western blot of cortical neurons lysates exposed to 12 or $24 \mathrm{~h}$ hypoxia with or without $A \beta_{1-42}$ using Caspase 3, Bax, and Bcl-2 antibodies. $\beta$ actin served as loading control. Densitometric analysis shows that after 12 and $24 \mathrm{~h}$ of hypoxia a significant increase in pro-apototic parameters (cleaved caspase 3 and Bax) occurs, while the levels of the Bcl-2 antiapoptotic protein are significantly reduced. The addition of $A \beta_{1-42}$ exacerbates the phenomenon leading to an increase in the pro-apoptotic parameters and a decrease in Bcl-2 that result significant if compared to cells incubated in hypoxia alone. C) Cell viability evaluated with MTT kit. The cell viability is significantly reduced after $24 \mathrm{~h}$ of hypoxia; the addition of A $\beta_{1-42}$ significantly reduced neuronal viability as early as $12 \mathrm{~h}$. Experiments are conducted in triplicate. The data are the mean \pm standard error (SEM). ${ }^{*} p<0.05$ versus control; ${ }^{* *} p<0.02$ versus control; $p<0.05$ versus hypoxia alone. 


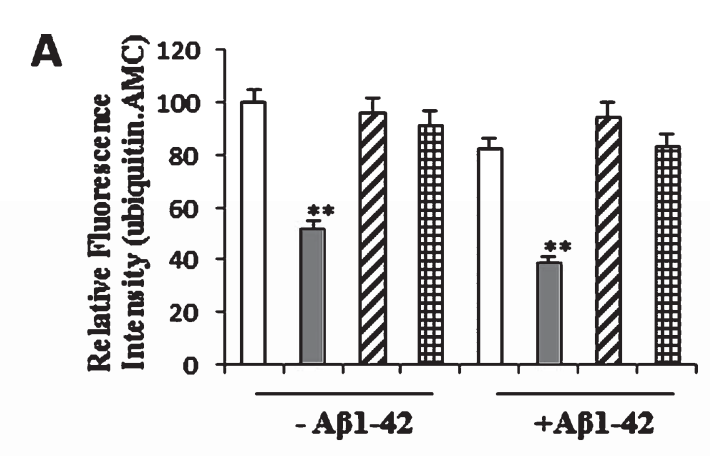

B

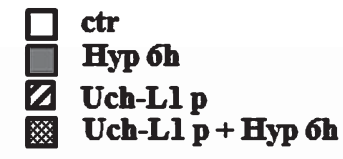

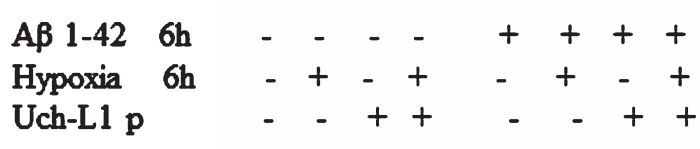

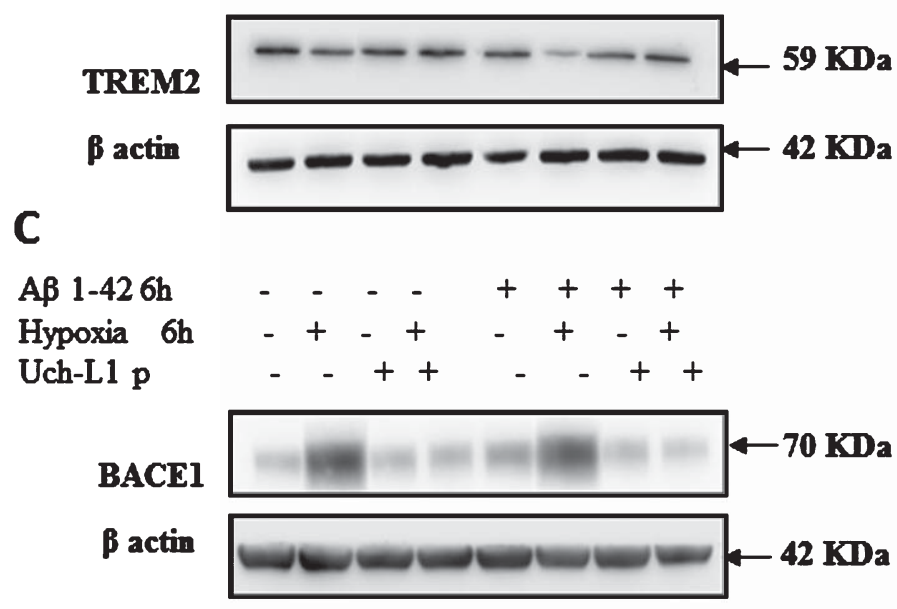

Densitometric analysis
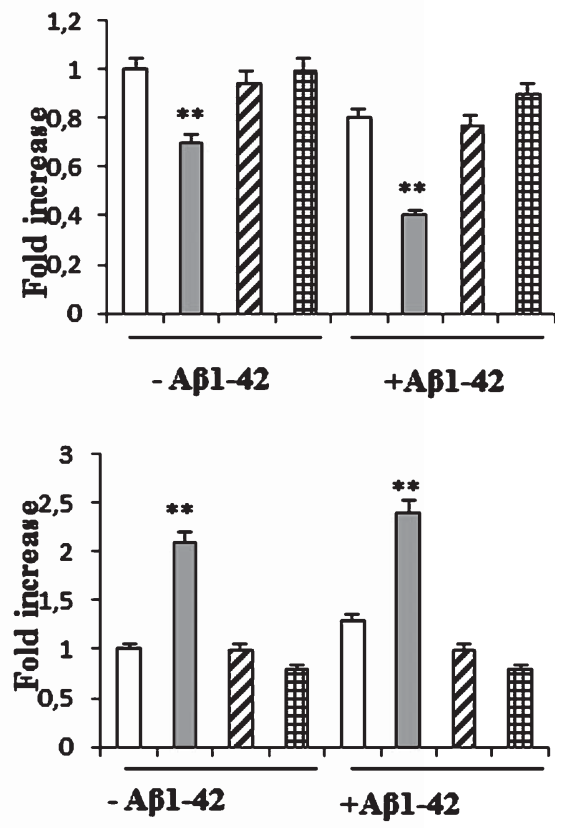

D

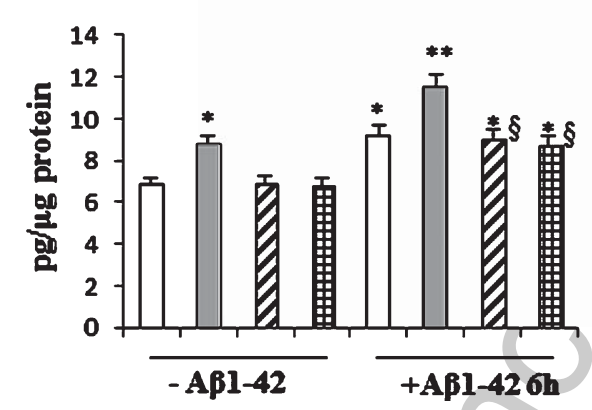

$\mathbf{E}$

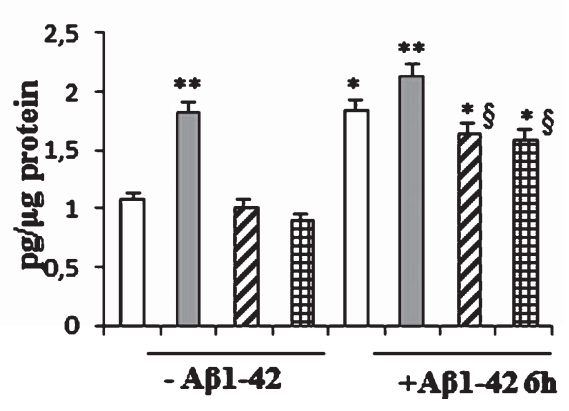

Fig. 3. Restoration of Uch-L1 activity rescues the decrease of TREM2 and the increase of BACE1 protein levels as well as the cytokine production. A) Hydrolase activity in cortical neurons exposed up to $6 \mathrm{~h}$ hypoxia with or without A $\beta_{1-42}$. The treatment of cells with the TAT peptide restores the activity of the enzyme. B) Representative western blot of cortical neurons lysates exposed to $6 \mathrm{~h}$ hypoxia with or without $\mathrm{A} \beta_{1-42}$ using TREM 2 antibody. $\beta$ actin served as loading control. Densitometric analysis shows that the restoration of the Uch-L1 activity abolishes the TREM2 decrease. C) Representative western blot of cortical neurons lysates exposed to $6 \mathrm{~h}$ hypoxia with or without A $\beta_{1-42}$ using BACE1 antibody. $\beta$ actin served as loading control. Densitometric analysis shows that the restoration of the Uch-L1 activity abolishes the BACE1 increase. D, E) Production of IL- 6 and TNF $\alpha$ in cells exposed to $6 \mathrm{~h}$ hypoxia with or without A $\beta_{1-42}$. Treatment with Uch-L1 TAT peptide rescues the increase of IL6 and TNF $\alpha$ after exposure to hypoxia alone; in co-presence of A $\beta_{1-42}$ the peptide significantly reduces the production of cytokines but levels are still slightly higher if compared to the control cells. Experiments are conducted in triplicate. The data are the mean \pm standard error $(\mathrm{SEM}) .{ }^{*} p<0.05$ versus control; ${ }^{* *} p<0.02$ versus control; $p<0.05$ versus hypoxia alone. 

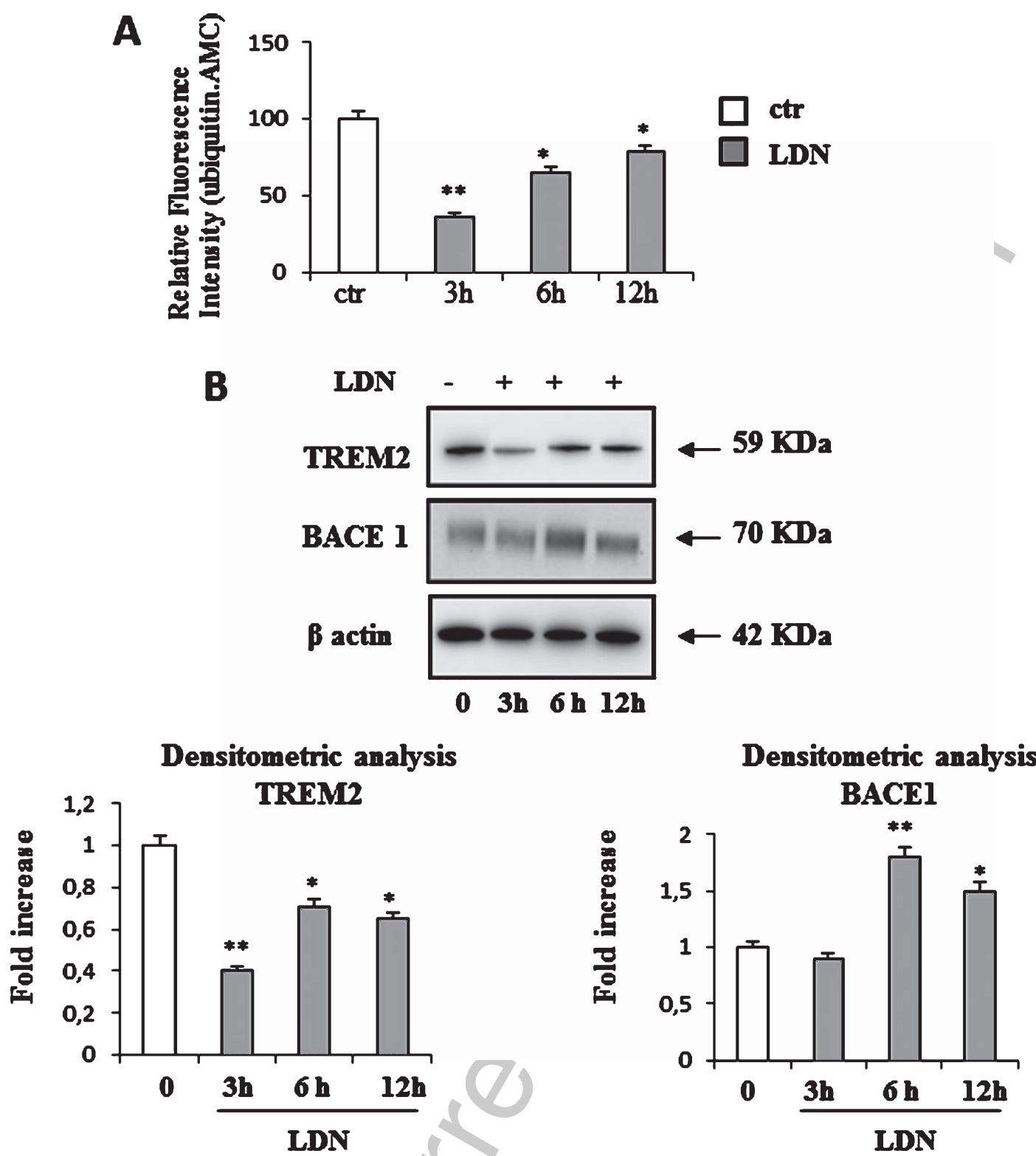

Fig. 4. The decrease in Uch-L1 activity is directly responsible for the decrease in TREM2. A) In normoxic conditions cortical cells are treated with $5 \mu \mathrm{M} \mathrm{LDN}-57444$ (LDN), a reversible Uch-L1 inhibitor, up to $12 \mathrm{~h}$. The treatment with LDN is followed by a decrease of total hydrolase activity. B) Representative western blot of cortical neurons lysates exposed up to $12 \mathrm{~h}$ to LDN in normoxic conditions using TREM2 and BACE1 antibodies. $\beta$ actin served as loading control. Densitometric analyses show the basal levels of TREM2 and BACE1 in presence of Uch-L1 inhibition. The levels of BACE1 are significantly higher than in control cells and the inhibition of Uch-L1 causes a significant decrease in TREM2. Experiments are conducted in triplicate. The data are the mean \pm standard error (SEM). ${ }^{*} p<0.05$ versus control; ${ }^{* *} p<0.02$ versus control.

with Uch-L1 peptide the values of the parameters become normal (Fig. 5C, D). Finally, we have shown that the production of inflammatory cytokines is also increased in both control and transgenic animals. The restoration of Uch-L1 completely abolishes the overproduction of inflammatory cytokines (Fig. 5E, F).
Uch-L1 and TREM2 are decreased in the cerebral cortex in patients with $A D$

It is well known that BACE 1 protein levels and activity were increased in $\mathrm{AD}$ cortex as compared to normal aging controls [28, 29]. The levels of Uch-L1 and BACE1 have an opposite trend, as 
previously reported [6] (Fig. 6A, C), but we have also shown that TREM2 protein levels are lower in AD cortex $(-40 \%)$ respect to normal aging controls (Fig. 6B). Finally, we measured the levels of p50, the
$\mathrm{NF}-\kappa \mathrm{B}$ subunit that mostly increases in the in vitro model. As can be seen, p50 levels in AD patient samples are significantly increased respect to controls (2-fold increase) (Fig. 6D).

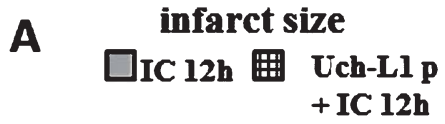
a

C

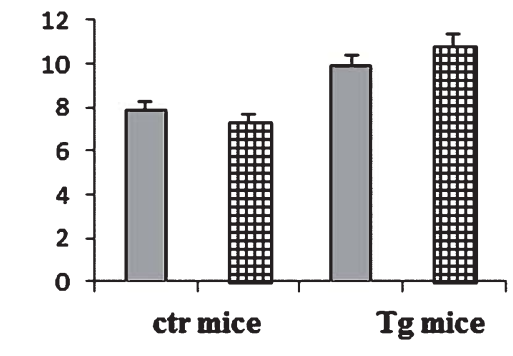

Ischemic

Injury (IC)

$12 \mathrm{~h}$

Uch-L1 p

TREM2

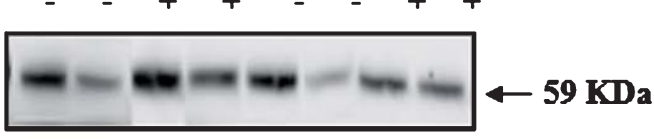

$\beta$ actin

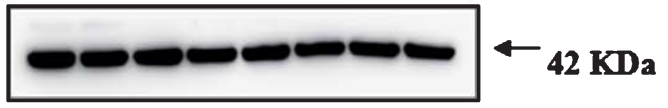

D

Ischemic

Injury (IC)

12h

Uch-Ll p

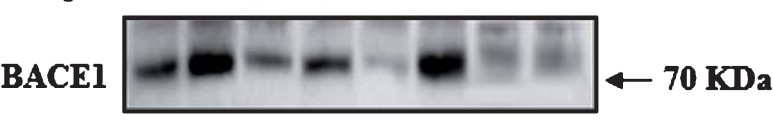

B actin

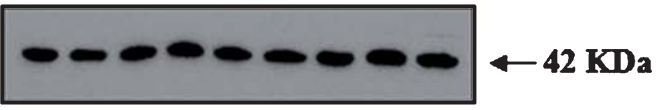

B brain edema

IC 12h 囲Uch-Ll p

+ IC $12 \mathrm{~h}$

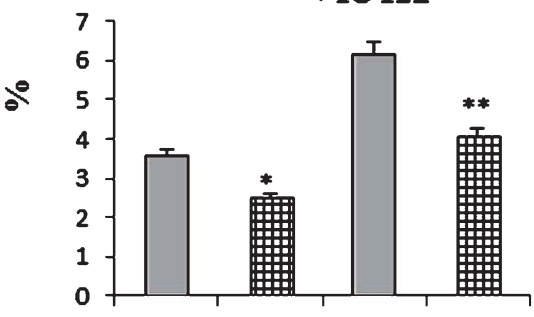

ctr mice Tg mice
432

433

Densitometric analysis

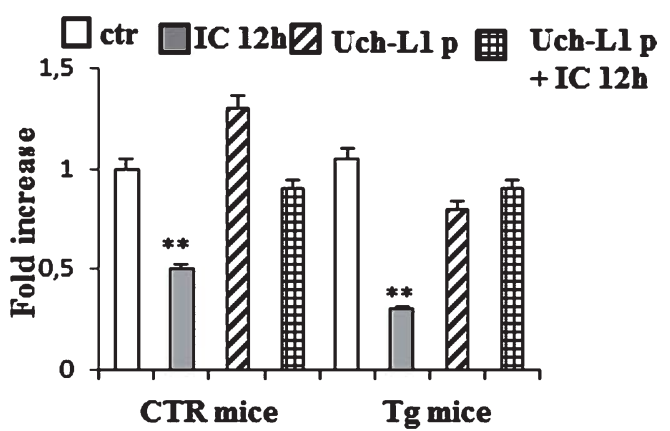

Densitometric analysis
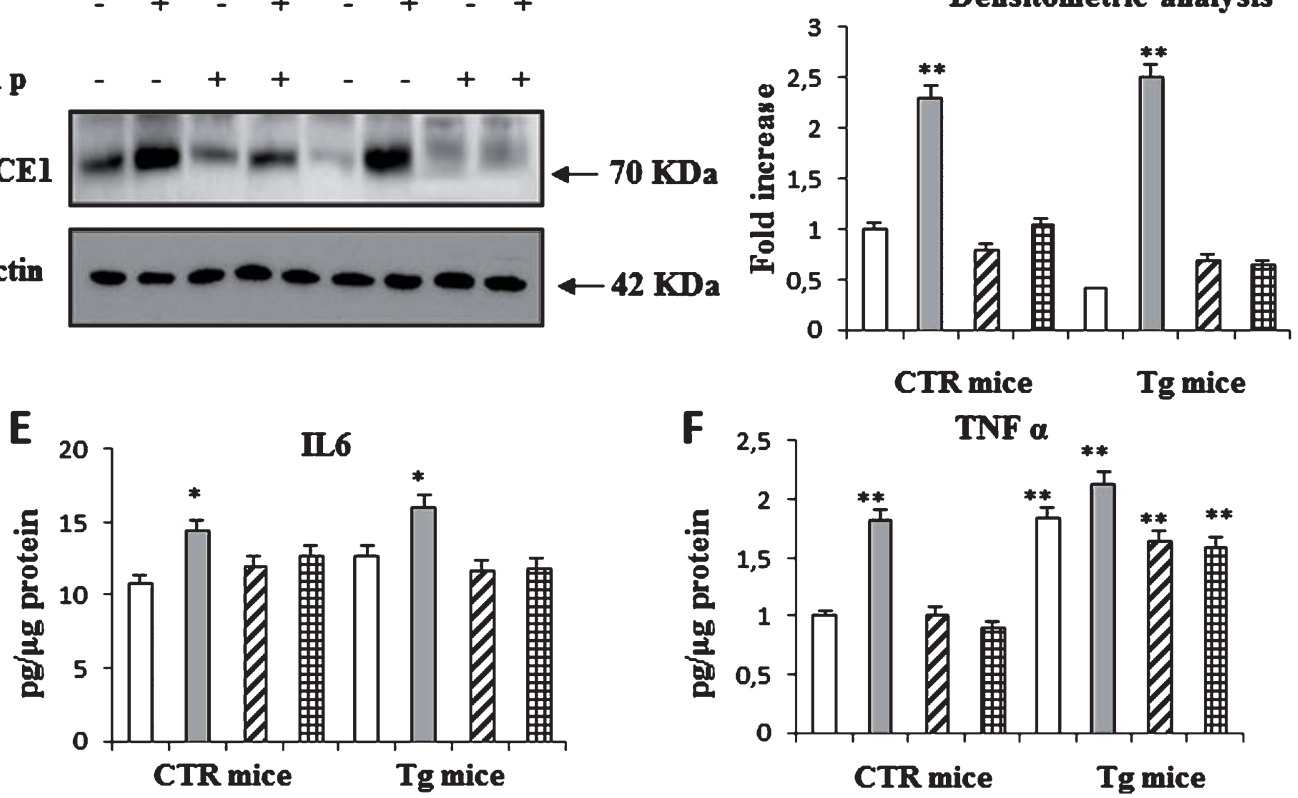


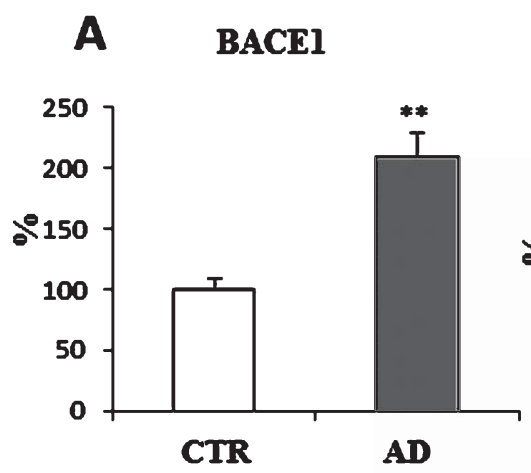

B

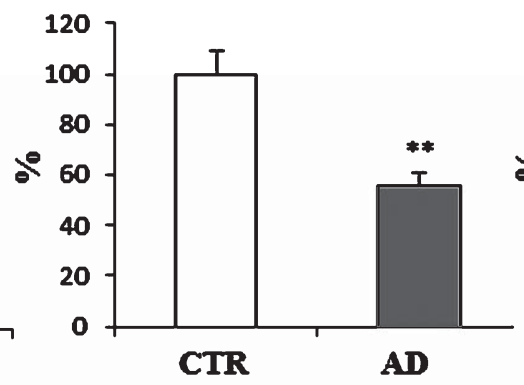

C

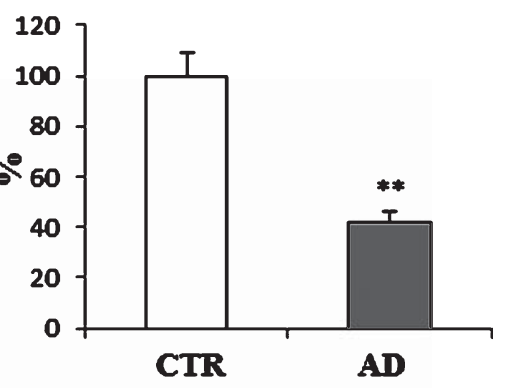

D
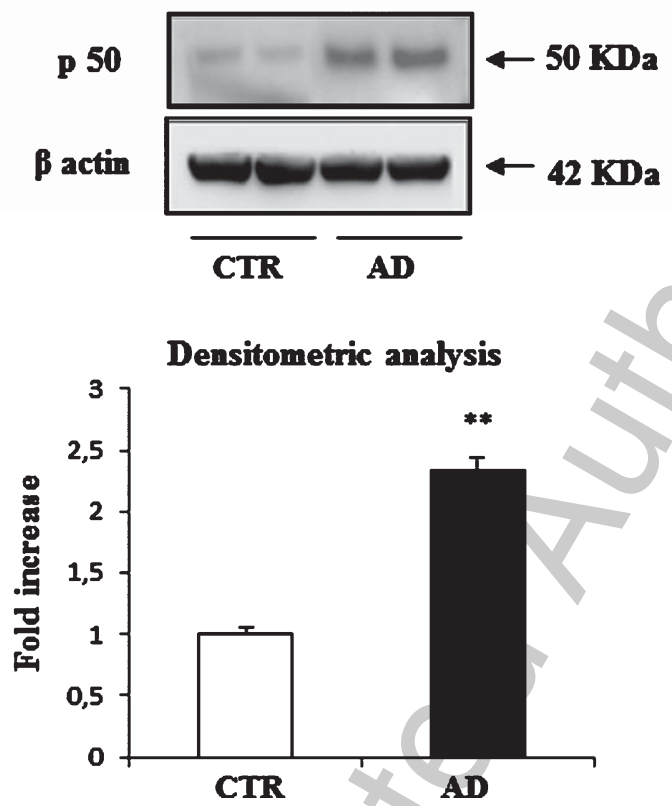

Fig. 6. Uch-L1 and TREM2 are decreased in the cerebral cortex of patients with AD. A-C) Histograms show BACE1, TREM2, and Uch-L1 levels in cortical brains samples in normal aging and AD patients. The levels of Uch-L1 and BACE1 have an opposite trend, TREM2 protein levels are significant lower in AD cortex with respect to normal aging controls. D) Representative western blot of cortical brains samples of normal aging and AD patients. $\beta$ actin served as loading control. Densitometric analyses show that p50 levels are significantly increased in $\mathrm{AD}$ samples. The data are the mean \pm standard error $(\mathrm{SEM}) .{ }^{* *} p<0.02$ versus normal aging.

\section{DISCUSSION}

The data presented in this work demonstrate that the activation of NF- $\kappa \mathrm{B}$ pathway, induced by ischemic damage with or without the presence of $\mathrm{A} \beta_{1-42}$, determines a significant decrease of TREM2 and of Uch-L1. These two proteins are strictly related

Fig. 5. The link between Uch-L1, TREM2, and BACE1 and neuroinflammation is confirmed in Tg mouse. We have performed experiments in control mice and in 5xFAD Tg mice subjected or not to proximal middle cerebral artery (MCA) electrocoagulation and sacrificed after $12 \mathrm{~h}$. A) The histogram shows the infarct area in controls and Tg subjected to ischemia; the area is almost similar both in control and Tg mice, and the pre-treatment with Uch-L1 TAT peptide does not change the size of the infarct area. B) The histogram shows the amount of brain edema calculated using Neurolucida Software. The restoration of the Uch-L1 activity significantly reduces the edema both in control as well as in Tg mice. C, D) Representative western blot of brain extracts from control and Tg mice exposed to $12 \mathrm{~h}$ of stroke and then sacrificed. $\beta$ actin served as loading control. Densitometric analyses show that in both control and transgenic animals the ischemic damage causes a decrease in TREM2 and a parallel increase in BACE1; the pre-treatment with Uch-L1 peptide returns the protein levels to those of control. E, F) Production of IL- 6 and TNF $\alpha$ in control or Tg mice exposed to $12 \mathrm{~h}$ of stroke. The restoration of Uch-L1 protects the overproduction of inflammatory cytokines. The data are the mean \pm standard error $(\mathrm{SEM}) .{ }^{*} p<0.05$ versus control mice; ${ }^{* *} p<0.02$ versus control mice. $\mathrm{N}=6$. 
to inflammation and aberrant protein processing. Inflammation is characterized by reactive morphological change of glial cells, including both astrocytes and microglia, and by release of cytokines in the parenchyma. However, this reaction is common to all neurodegenerative diseases and to ischemic and traumatic damage. Given this poor specificity, it can be concluded that the glial reaction is secondary to neuronal dysfunction and death [30]. Assessing the role of these cells in the pathogenesis of neurodegenerative diseases has led to the study of the association between Nasu-Hakola disease and TREM2, a gene expressed only on microglial cells [19]. Although this disease is rare, the study was the first scientific confirmation that dementia may be due to microglial dysfunction and that the microglial integrity is a fundamental requirement for brain homeostasis. In AD, genome-wide association studies have identified 20 validated risk genes, about half of which are expressed predominantly or exclusively by microglial cells [20, 31]. For example, ApoE is mainly expressed in astrocytes and reactive microglia [32]. The stimulation of neuroinflammation is also strictly related to vascular disruption and ischemic injury. It has been demonstrated that the release of monomeric-C-reactive protein within brain tissue could exacerbate ongoing neurological damage via stimulation of neuroinflammation and from direct consequences of its action on both neuronal and vascular cells [33]. Moreover, the TREM-2 activation by antibody cross-linking or the overexpression of TREM-2 intracellular adaptor, DAP12, abolishes the hypoxia-induced NF- $\kappa \mathrm{B}$ activation in purified astrocytic cultures [34]. In vivo, TREM2 expression was observed in macrophages and astrocytes located in the ischemic penumbra [34]. Recently, it has been found that upregulation of TREM2 accelerates the reduction of amyloid deposits in $A \beta_{42}$ injected mice. The authors found that $A \beta_{42}$ injection decreases the TREM 2 levels and pretreatment of mice with an inhibitor of NF-kB pathway increases TREM2 and decreases amyloid deposits [35].

The ubiquitin-proteasome system (UPS) is a major pathway for protein degradation. The pathogenesis of many neurodegenerative diseases, including AD, is associated with the downregulation of the UPS [11]. Indeed, Uch-L1, the limiting step of proteasomal degradation, is decreased in AD brains [12], and its level is inversely proportional to the amount of tau pathology [13].
It is well known that prostaglandin $\mathrm{J} 2$, an inflammatory molecule, induces accumulation and aggregation of ubiquitinated proteins through a decrease in proteasome activity [36]. Indeed, it has been demonstrated that prostaglandin $\mathrm{J} 2$ impairs the 26S proteasome [37]. In particular, in neuronal cells J2 prostaglandins oxidize the S6 ATPase, a subunit that is considered extremely vulnerable to protein carbonylation [38]. Then, prostaglandins impair UPS through the unfolding and aggregation of Uch-L1, by forming a covalent adduct [39].

We now show that the restoration of the UchL1 activity is able not only to protect against the overexpression of BACE1, as already demonstrated, but also to significantly diminish neuroinflammation, expressed by less cytokine production, both in vitro and in vivo, and by a drastic decrease of periinfarctual edema, in brains of mice (Fig. 6).

The anti-inflammatory effect of Uch-L1 activity could be related to the degradation of BACE1 at the lysosomal level [6] and therefore to the interruption of a continuous production of $A \beta_{1-42}$, that is certainly linked to the release of inflammatory cytokines and oxidative stress responsible for inflammation. As a consequence, the restoration of Uch-L1 could represent an innovative therapeutic approach able to interrupt not only the abnormal processing of $\mathrm{A} \beta \mathrm{PP}$ but also to improve the neuroinflammation.

\section{ACKNOWLEDGMENTS}

This study was supported by University of Genoa (MT), Regione Piemonte (ET), and University of Torino (ET). We thank Dr. Ottavio Arancio, Professor at Columbia University, New York, who provided us with the Uch-L1 restoration peptide.

Authors' disclosures available online (https:// www.j-alz.com/manuscript-disclosures/19-0494r2).

\section{REFERENCES}

[1] Chitnis T, Weiner HL (2017) CNS inflammation and neurodegeneration. J Clin Invest 127, 3577-3587.

[2] Srinivasan M, Lahiri DK (2015) Significance of NF- $\kappa$ B as a pivotal therapeutic target in the neurodegenerative pathologies of Alzheimer's disease and multiple sclerosis. Expert Opin Ther Targets 19, 471-487.

[3] Shi ZM, Han YW, Han XH, Zhang K, Chang YN, Hu ZM, Qi HX, Ting C, Zhen Z, Hong W (2016) Upstream regulators and downstream effectors of NF- $\kappa \mathrm{B}$ in Alzheimer's disease. J Neurol Sci 366, 127-134. 
[4] Buggia-Prevot V, Sevalle J, Rossner S, Checler F (2008) NFkappaB-dependent control of BACE1 promoter transactivation by Abeta42. J Biol Chem 283, 10037-10047.

[5] Chen CH, Zhou W, Liu S, Deng Y, Cai F, Tone M, Tone $\mathrm{Y}$, Tong Y, Song W (2012) Increased NF- $\kappa$ B signalling upregulates BACE1 expression and its therapeutic potential in Alzheimer's disease. Int J Neuropsychopharmacol 15, 77-90.

[6] Guglielmotto M, Monteleone D, Boido M, Piras A, Giliberto L, Borghi R, Vercelli A, Fornaro M, Tabaton M, Tamagno E (2012) A $\beta 1$-42-mediated down-regulation of Uch-L1 is dependent on NF- $\kappa$ B activation and impaired BACE1 lysosomal degradation. Aging Cell 11, 834-844.

[7] Guglielmotto M, Monteleone D, Vasciaveo V, Repetto IE, Manassero G, Tabaton M, Tamagno E (2017) The decrease of Uch-L1 activity is a common mechanism responsible for A $\beta 42$ accumulation in Alzheimer's and vascular disease. Front Aging Neurosci 9, 320.

[8] Zhang H, Sun Y, Hu R, Luo W, Mao X, Zhao Z, Chen Q, Zhang Z (2013) The regulation of the UCH-L1 gene by transcription factor NF- $\kappa$ B in podocytes. Cell Signal 25, 1574-1585.

[9] Gong B and Leznik E (2007) The role of ubiquitin Cterminal hydrolase L1 in neurodegenerative disorders. Drug News Perspect 20, 365-370.

[10] Liu Y, Fallon L, Lashuel HA, Liu Z, Lansbury PT Jr (2002) The UCH-L1 gene encodes two opposing enzymatic activities that affect alpha-synuclein degradation and Parkinson's disease susceptibility. Cell 111, 209-218.

[11] Zheng Q, Huang T, Zhang L, Zhou Y, Luo H, Xu H, Wang $X$ (2016) Dysregulation of ubiquitin-proteasome system in neurodegenerative diseases. Front Aging Neurosci 8, 303.

[12] Choi J, Levey AI, Weintraub ST, Rees HD, Gearing M, Chin LS, Li L (2004) Oxidative modifications and downregulation of ubiquitin carboxyl-terminal hydrolase L1 associated with idiopathic Parkinson's and Alzheimer's diseases. J Biol Chem 279, 13256-13264.

[13] Poon WW, Carlos AJ, Aguilar BL, Berchtold NC, Kawano CK, Zograbyan V, Yaopruke T, Shelanski M, Cotman CW (2013) $\beta$-Amyloid (A $\beta$ ) oligomers impair brain-derived neurotrophic factor retrograde trafficking by down-regulating ubiquitin C-terminal hydrolase, UCH-L1. J Biol Chem 288, 16937-16948.

[14] Xie M, Han Y, Yu Q, Wang X, Wang S, Liao X (2016) UCHL1 inhibition decreases the microtubule-binding function of tau protein. J Alzheimers Dis 49, 353-363.

[15] Ichikawa T, Li J, Dong X, Potts JD, Tang DQ, Li DS, Cui T (2010) Ubiquitin carboxyl terminal hydrolase L1 negatively regulates TNFalpha-mediated vascular smooth muscle cell proliferation via suppressing ERK activation. Biochem Biophys Res Commun 391, 852-856.

[16] Zhong L, Zhang ZL, Li X, Liao C, Mou P, Wang T, Wang Z, Wang Z, Wei M, Xu H, Bu G, Chen XF (2017) TREM2/DAP1 2 complex regulates inflammatory responses in microglia via the JNK signaling pathway. Front Aging Neurosci 9, 204.

[17] Han J, Wang M, Ren M, Lou H (2017) Contributions of triggering-receptor-expressed-on-myeloid-cells-2 to neurological diseases. Int J Neurosci 127, 368-375.

[18] Cheng J, Guo X, Zhang T, Zhong L, Bu G, Chen X (2016) TREMs in Alzheimer's disease: Genetic and clinical investigations. Clin Chim Acta 463, 88-95.

[19] Dardiotis E, Siokas V, Pantazi E, Dardioti M, Rikos D, Xiromerisiou G, Markou A, Papadimitriou D, Speletas M, Hadjigeorgiou GM (2017) A novel mutation in TREM2 gene causing Nasu-Hakola disease and review of the literature. Neurobiol Aging 53, 194.e13-194.e22.

[20] Carmona S, Zahs K, Wu E, Dakin K, Bras J Guerreiro R (2018) The role of TREM2 in Alzheimer's disease and other neurodegenerative disorders. Lancet Neurol 17, 721-730.

[21] Backhauss C, Karkoutly C, Welsch M, Krieglstein J (1992) A mouse model of focal cerebral ischemia for screening neuroprotective drug effects. J Pharmacol Toxicol Methods 27, 27-32

[22] Dohare P, Garg P, Jain V, Nath C, Ray M (2008) Dose dependence and therapeutic window for the neuroprotective effects of curcumin in thromboembolic model of rat. Behav Brain Res 193, 289-297.

[23] Gong B, Cao Z, Zheng P, Vitolo OV, Liu S, Staniszewski A, Moolman D, Zhang H, Shelanski M, Arancio O (2006) Ubiquitin hydrolase Uch-L1 rescues beta-amyloid-induced decreases in synaptic function and contextual memory. Cell 126, $775-788$.

[24] Manassero G, Guglielmotto, M, Zamfir R, Borghi, Colombo L, Salmona M, Perry G, Odetti P, Arancio O, Tamagno E, Tabaton M (2016) Beta-amyloid 1-42 monomers, but not oligomers, produce PHF-like conformation of Tau protein. Aging Cell 15, 914-923.

[25] Wang R, Zhang M, Zhou W, Ly PT, Cai F, Song $\mathrm{W}(2011) \mathrm{NF}_{-} \mathrm{B}$ s signaling inhibits ubiquitin carboxylterminal hydrolase L1 gene expression. J Neurochem 116 , 1160-1170.

[26] Jiang T, Yu JT, Zhu XC, Tan MS, Gu LZ, Zhang YD, Tan L (2014) Triggering receptor expressed on myeloid cells 2 knockdown exacerbates aging-related neuroinflammation and cognitive deficiency in senescence-accelerated mouse prone mice. Neurobiol Aging 35, 1243-1251.

[27] Zhang X, Yan F, Cui J, Wu Y, Luan H, Yin M, Zhao Z, Feng J, Zhang J (2017) Triggering receptor expressed on myeloid cells 2 overexpression inhibits proinflammatory cytokines in lipopolysaccharide-stimulated microglia. Mediators Inflamm 2017, 9340610.

[28] Holsinger RM, McLean CA, Beyreuther K, Masters CL, Evin G (2002) Increased expression of the amyloid precursor beta-secretase in Alzheimer's disease. Ann Neurol 51, 783-786.

[29] Borghi R, Patriarca S, Traverso N, Piccini A, Storace D, Garuti A, Gabriella Cirmena, Patrizio Odetti, Massimo Tabaton (2007) The increased activity of BACE1 correlates with oxidative stress in Alzheimer's disease. Neurobiol Aging 28, 1009-1014.

[30] Ransohoff RM (2016) How neuroinflammation contributes to neurodegeneration. Science 353, 777-783.

[31] Villegas-Llerena C, Phillips A, Garcia-Reitboeck P, Hardy J, Pocock JM (2016) Microglial genes regulating neuroinflammation in the progression of Alzheimer's disease. Curr Opin Neurobiol 36, 74-81.

[32] Bennett ML, Bennett FC, Liddelow SA, Ajami B, Zamanian JL, Fernhoff NB, Mulinyawe SB, Bohlen CJ, Adil A, Tucker A, Weissman IL, Chang EF, Li G, Grant GA, Hayden Gephart MG, Barres BA (2016) New tools for studying microglia in the mouse and human CNS. Proc Natl Acad Sci U S A 113, E1738-E1746.

[33] Slevin M, Liu D, Ferris G, Al-Hsinawi M, Al-Baradie R, Krupinski J (2017) Expression of monomeric Creactive protein in infarcted brain tissue from patients with Alzheimer's disease. Turk Patoloji Derg 33, 25-29.

[34] Rosciszewski G, Cadena V, Murta V, Lukin J, Villarreal A, Roger T, Ramos AJ (2018) Toll-like receptor 4 (TLR4) and triggering receptor expressed on myeloid cells-2 (TREM-2) 
activation balance astrocyte polarization into a proinflammatory phenotype. Mol Neurobiol 55, 3875-3888.

[35] Fan Y, Ma Y, Huang W, Cheng X, Gao N, Li G, Tian S (2019) Up-regulation of TREM2 accelerates the reduction of amyloid deposits and promotes neuronal regeneration in the hippocampus of amyloid beta1-42 injected mice. JChem Neuroanat 97, 71-79.

[36] Figueiredo-Pereira ME, Rockwell P, Schmidt-Glenewinkel T, Serrano P (2015) Neuroinflammation and J2 prostaglandins: Linking impairment of the ubiquitin-proteasome pathway and mitochondria to neurodegeneration. Front Mol Neurosci 7,104.

[37] Wang Z, Aris VM, Ogburn KD, Soteropoulos P, FigueiredoPereira ME (2006) Prostaglandin J2 alters pro-survival and pro-death gene expression patterns and $26 \mathrm{~S}$ proteasome assembly in human neuroblastoma cells. J Biol Chem 281, 21377-21386.
[38] Ishii T, Sakurai T, Usami H, Uchida K (2005) Oxidative modification of proteasome: Identification of an oxidationsensitive subunit in $26 \mathrm{~S}$ proteasome. Biochemistry $\mathbf{4 4}$, 13893-13901.

[39] Koharudin LM, Liu H, Di Maio R, Kodali RB, Graham SH Gronenborn AM (2010) Cyclopentenone prostaglandininduced unfolding and aggregation of the Parkinson disease-associated UCH-L1. Proc Natl Acad Sci U S A 107, 6835-6840. 